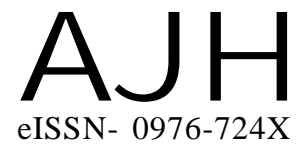

Received : 13.01.2015

Revised : 23.10.2015

Accepted : 08.11.2015
Members of the Research Forum

Associated Authors:

${ }^{1}$ Post Graduate College, GHAZIPUR (U.P.) INDIA
Author for correspondence : HEMANT KUMAR SINGH

Post Graduate College, GHAZIPUR (U.P.) INDIA
THEASIAN JOURNALOF HORTICULTURE

Volume 10 | Issue 2 | December, 2015 | 212-215

Visit us -www.researchjournal.co.in

RESEARCH PAPER

\section{Association and path co-efficient analysis among yield and its components in bitter gourd (Momordica charantia L.)}

\section{HEMANT KUMAR SINGH AND D.R. SINGH ${ }^{1}$}

ABSTRACT : Correlation and path analysis were carried out in order to quantify the contribution of explanatory characters towards yield for bitter gourd cultivation. The characters like number of fruits per plant and fruit length had significant and positive correlation with yield. Number of fruits per plant and average fruit weight had the highest positive direct effect on fruit yield per plant.

KEY WORDS : Bitter gourd, Association, Path co-efficient

HOW TO CITE THIS ARTICLE : Singh, Hemant Kumar and Singh, D.R. (2015). Association and path co-efficient analysis among yield and its components in bitter gourd (Momordica charantia L.). Asian J. Hort., 10(2) : 212-215. 